\title{
Analysis of Student's Ability in Creative Thinking on Entrepreneurship Learning at Class IV SDN 3 Krakal
}

\author{
Universitas Sebelas Maret \\ usvah.kompo@gmail.com
}

Usvah Istikomah, Kartika Chrysti Suryandari

Article History

accepted 24/09/2019

approved 01/10/2019

published 01/12/2019

\begin{abstract}
This study aims to analyze the ability of students in creative thinking in entrepreneurial learning class IV Krakal 3 Elementary School 2019/2020. The design of this research is simple descriptive. The object of research is the ability to think creatively in entrepreneurial learning with indicators of fluency thinking, flexible thinking, original thinking and elaborative thinking. The research subjects were grade IV students with 20 students. Data analysis was performed using descriptive techniques and existing data in the form of qualitative data from observation sheets and student questionnaires which were then described. The results showed that overall creative abilities included thinking fluency that was already good with a percentage of $78.75 \%$, flexible thinking also showed quite good results with a percentage of $64.37 \%$, Original Thinking was categorized quite well with a percentage of $68.12 \%$, and Thinking Elaborative categorized quite well with a percentage of $70.62 \%$. This shows that students are able to think creatively in entrepreneurship learning.
\end{abstract}

.Keywords: Creative, Entrepreneurship Learning, Elementary School

\begin{abstract}
Abstrak
Penelitian ini bertujuan untuk menganalisis kemampuan siswa dalam berpikir kreatif pada pembelajaran kewirausahan kelas IV SD Negeri 3 Krakal tahun ajaran 2019/2020. Desain penelitian ini berupa deskriptif sederhana. Objek penelitian adalah kemampuan berpikir kreatif pada pembelajaran kewirausahan dengan indikator keterampilan berpikir lancar (Fluency), berpikir luwes (Flexibility), berpikir orisinil (Originality) dan berpikir elaboratif (Elaboration). Subjek penelitian yaitu siswa kelas IV berjumlah 20 siswa. Analisis data dilakukan dengan teknik deskriptif dan data-data yang ada berupa data kualitatif dari lembar observasi dan angket siswa yang kemudian dideskripsikan. Hasil penelitian menunjukan bahwa secara keseluruhan kemampuan kreatif meliputi berpikir lancar yang sudah baik dengan prosentase $78,75 \%$, berpikir luwes juga menunjukan hasil yang cukup baik dengan prosentase $64,37 \%$, berpikir orisinil dikatagorikan cukup baik dengan persentase $68,12 \%$, dan berpikir elaboratif dikatagorikan cukup baik dengan presentase $70,62 \%$. Hal tersebut menunjukan bahwa siswa mampu berfikir kreatif dalam pembelajaran kewirausahaan.
\end{abstract}

Kata kunci: Kreatif, Pembelajaran Kewirausahaan, Sekolah Dasar.

Social, Humanities, and Education Studies (SHEs): Conference Series https://jurnal.uns.ac.id/shes

p-ISSN 2620-9284

e-ISSN 2620-9292 


\section{PENDAHULUAN}

Era revolusi industri 4.0 ditandai dengan semakin biasnya dunia nyata dan digital serta menghadirkan peluang dan tantangan baru. Munculnya tantangan baru dalam bidang ekonomi membuat beberapa pekerjaan yang tidak dapat beradaptasi di era ini akan tidak terpakai dan pada akhirnya hilang. Menurut Badan Pusat Statistik (2017) Jumlah angkatan kerja pada Agustus 2018 sebanyak 131,01 juta orang, naik 2,95 juta orang dibanding Agustus 2017. Sejalan dengan itu, Tingkat Partsipasi Angkatan Kerja (TPAK) juga meningkat 0,59 persen poin. Dalam setahun terakhir, pengangguran berkurang 40 ribu orang, sejalan dengan TPT yang turun menjadi 5,34 persen pada Agustus 2018. Dilihat dari tngkat pendidikan, TPT untuk Sekolah Menengah Kejuruan (SMK) masih mendominasi di antara tngkat pendidikan lain, yaitu sebesar 11,24 persen. Data tersebut menunjukkan perlunya perbaikan kualitas sumber daya manusia dalam menyikapi keadaan dan tantangan di era ini, serta masyarakat diharapkan dapat mengubah pola pikir dari pencari kerja (job seeker) menjadi pencipta lapangan pekerjaan (job creator) agar jumlah pengangguran terbuka tidak terus meningkat tiap tahunnya. Dari permasalahan tersebut maka perlu adanya pendidikan kewirausahaan sejak dini agar terbentuknya sikap, jiwa, dan kemampuan untuk menciptakan sesuatu yang baru serta sangat berguna bagi dirinya dan orang lain.

Dalam menghadapi era revolusi industri 4.0 guru masih disibukkan oleh beban penyampaian muatan pengetahuan dan ditambah berbagai tugas administratif yang terlalu padat sehingga tidak lagi memiliki waktu tersisa memberi peluang anak didik menjelajahi daya-daya kreatif mereka menghasilkan karya-karya orisinal. Akibatnya, interaksi sosial anak didik terbatasi, daya kreasinya terbelenggu. Menanggapi masalah diatas sekolah perlu menambah pembelajaran kewirausahaan agar siswa mampu mengembangkan jiwa kreatif dengan adanya dasar pen- didikan kewirausahaan sedini mungkin. Di Indonesia jenjang pendidikan dasar masih belum ada mata pelajaran kewirausahaan, Oleh karena itu untuk memberikan pen- didikan kewirausahaan pada siswa sekolah dasar diperlukan perangkat pembelajaran kewirausahaan yang diterapkan melalui pembelajaran di setiap satuan pendidikan mulai dari Pendidikan Anak Usia Dini hingga Sekolah Menengah. Selaras dengan masalah dan penerapan pendidikan kewirausahaan tersebut, SD Negeri 3 Krakal menyelenggarakan pendidikan kewirausahaan yang bertujuan untuk menumbuh semangat wirausaha peserta didik. Selain itu, dalam pendidikan keiwrausahaan juga terdapat nilai-nilai yang dapat dikembangkan sebagai modal peserta didik untuk mengahadapi era revolusi industry 4.0. Salah satu nilai tersebut yaitu kemampuan berpikir kreatif.

Sani (2014:15) mengemukakan bahwa berpikir kreatif merupakan kemampuan mengembangkan ide yang tidak biasa, berkualitas, dan sesuai tugas. Menurut Susanto (2013:110), berpikir kreatif merupakan sebuah proses yang melibatkan unsur-unsur orisinalitas, kelancaran, fleksibelitas, dan elaborasi. Hal tersebut menunjukan bahwa berfikir kreatif dapat mengembangkan daya pikir yang mencangkup wawasan dengan unsur unsur yang luas. Sejalan dengan Susanto, Febrianti, dkk. (2016) menyatakan bahwa berpikir kreatif memberikan dukungan kepada peserta didik sehingga peserta didik lebih terpacu untuk lebih kreatif. Berdasarkan beberapa pendapat ahli tersebut, dapat disimpulkan bahwa berpikir kreatif adalah kemampuan seorang individu untuk mengembangkan ide-ide yang tidak biasa dan menggabungkan ide-ide tersebut sehingga menghasilkan suatu pemikiran baru dan hasil yang berkualitas.

Salah satu tujuan pembelajaran kewirausahaan adalah membuat peserta didik berpikir kreatif dan inovatif baik untuk memecahkan masalah maupun untuk berkomunikasi atau menyampaikan pemikiran mereka. Tetapi kenyataannya penerapan pembelajaran kewirausahaan tidak mendorong siswa untuk berpikir kreatif.

Penelitian diajukan pada anak sekolah dasar (SD) karena pada jenjang tersebut sebagai dasar untuk peserta didik dapat menanamkan kemampuan berpikir kreatif yang didapatnya sebelum memasuki jenjang yang lebih tinggi dengan harapan siswa 
dapat lebih terbiasa untuk berpikir kreatif dan mengembangkan ide. Kelas IV dipilih karena pada jenjang kelas tersebut, guru menerapkan pembelajaran kewirausahaan yang dapat menumbuhkan kemampuan berpikir kreatif peserta didik.

Berdasarkan latar belakang diatas tujuan penelitian ini yaitu untuk menganalisis kemampuan siswa dalam berpikir kreatif dalam pembelajaran kewirausahaan SD Negeri 2 Kebumen tahun ajaran 2019/2020.

\section{METODE}

Pendekatan penelitian ini adalah pendekatan kualitatif dan jenis penelitian yang bersifat deskriptif mengacu pada (Sudaryono, dkk. 2013: 9). Subjek dalam penelitian ini adalah siswa kelas IV SD Negeri 3 Krakal yang berjumlah 20 orang yang terdiri dari 7 siswa perempuan dan 13 siswa laki-laki. Data penelitian ini berupa data kualitatif yaitu berupa kemampuan siswa dalam berpikir kratif dilihat berdasarkan kriteria sangat baik, baik, cukup baik, kurang baik, kurang sekali yang dilaksanakan di SD Negeri 3 Krakal pada semester ganjil tahun ajaran 2019/2020. Pengumpulan data dengan teknik observasi dan angket. Teknik analisis data menggunakan teknik analisis deskriptif kulitatif dimana data dan informasi yang diperoleh dari lapangan dideskripsikan secara kualitatif kemudian mengambil kesimpulan. Data dianalisis dengan rumus menurut Ali (2013) sebagai berikut:

$$
\text { Skor }=\frac{\text { Jumlah Skor }}{\text { Skor Maksimal }} x 100 \%
$$

Rumus ini bisa digunakan untuk mengkonversikan jawaban dari data yang telah dihitung. Adapun skalanya sebagai berikut:

\begin{tabular}{ll}
\hline \multicolumn{2}{c}{ SKALA PROSENTASE DATA } \\
\hline PROSENTASE & KETERANGAN \\
$86 \%-100 \%$ & Sangat Baik \\
$76 \%-85 \%$ & Baik \\
$60 \%-75 \%$ & Cukup Baik \\
$55 \%-59 \%$ & Kurang Baik \\
$<54 \%$ & Kurang Sekali \\
\hline \multicolumn{2}{c}{ ( Riduwan, 2012: 89 ) }
\end{tabular}

\section{HASIL DAN PEMBAHASAN}

Menurut Susanto (2013:110) Berpikir kreatif merupakan sebuah proses yang melibatkan unsur-unsur orisinalitas, kelancaran, fleksibelitas, dan elaborasi. Hal tersebut menunjukan bahwa berfikir kreatif dapat mengembangkan daya pikir yang mencangkup wawasan dengan unsur unsur yang luas.. Berdasarkan hasil pengisian angket oleh siswa yang dilakukan oleh peneliti terkait dalam berpikir kreatif peserta didik kelas IV di SD Negeri 3 Krakal dinilai dari aspek keterampilan berpikir lancar (Fluency);,keterampilan berpikir luwes (Flexibility), keterampilan berpikir orisinil (Originality ) dan keterampilan berpikir elaboratif (Elaboration). Data dalam penelitian dideskripsikan dalam diagram batang yang didapatkan dari pengisian angket oleh siswa dilihat berdasarkan kriteria sangat baik, baik, cukup baik, kurang baik, kurang sekali serta hasil observasi lapangan juga dideskripsikan secara kualitatif. 


\section{Hasil Penelitian menggunakan angket}

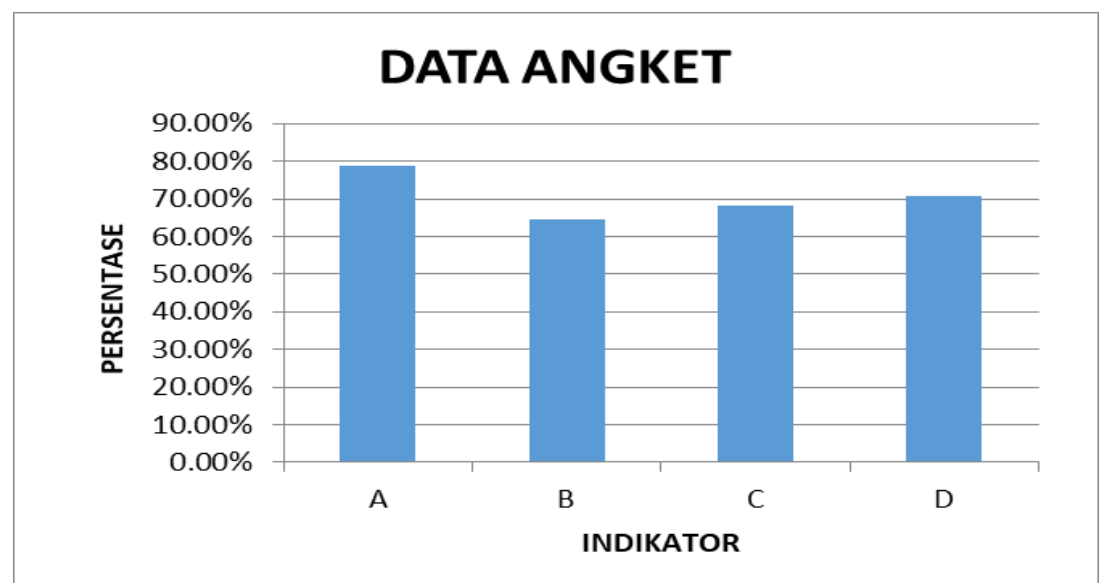

Gambar 1. Profil kemampuan Berpikir Kreatif dalam pembelajaran kewirausahaan kelas IV menggunakan angket.

Ket: $\boldsymbol{A}=$ Berpikir Lancar (Fluency); $\boldsymbol{B}=$ Berpikir Luwes (Flexibility); $\boldsymbol{C}=$ Berpikir Orisinil (Originality ); $\boldsymbol{D}=$ Berpikir Elaboratif (Elaboration).

Berdasarkan hasil analisis data yang diperoleh dari pengisian angket dilihat dari keterampilan berpikir lancar (Fluency) yang sudah baik dengan prosentase $78,75 \%$. Dilihat dari hasil tersebut kemampuan berpikir peserta didik dalam keterampilan ini ditunjukan oleh perilaku peserta didik, seperti mengajukan banyak pertanyaan kepada guru, menjawab pertanyaan dalam pembelajaran, mengerjakan tugas dengan cepat dan benar, dan memperbaiki hasil jika kurang memuaskan. Hal itu sejalan dengan pendapat Baer (dikutip Aryana, 2007:675) mengemukakan berpikir kreatif yaitu berpikir lancar, adalah kemampuan menghasilkan banyak ide dan gagasan.

Indikator selanjutnya yaitu keterampilan berpikir luwes (Flexibility) juga menunjukan hasil yang cukup baik dengan prosentase $64,37 \%$ dengan keterampilan ini peserta didik dapat menghasilkan gagasan, jawaban, atau pertanyaan yang baru dan dapat melihat masalah dari sudut pandang yang berbeda dan memikirkan macammacam cara yang berbeda-beda untuk menyelesaikan masalah/tugas. Hal tersebut sesuai dengan pendapat Susanto (2013) berpikir luwes, adalah kemampuan menghasilkan ide-ide yang bervariasi.

Sedangkan dalam indicator keterampilan berpikir orisinil (Originality) dikatagorikan cukup baik dengan persentase 68,12\% dengan keterampilan ini peserta didik memiliki cara berpikir yang lain dari yang lain dan mencari pendekatan yang baru dimana setelah membaca dan mendengar gagasan-gagasan peserta didik bekerja untuk menemukan penyelesaian yang baru, tidak meniru pekerjaan orang lain, membuat produk-produk yang belum pernah ada dan menyukai hal-hal yang baru. Hal ini sejalan dengan pendapat dari Zubaidah (2017) berpikir orisinal, adalah kemampuan menghasilkan ide baru atau ide yang sebelumnya tidak ada, menciptakan produk yang sebelumnya belum ada.

Kemudian untuk indicator keterampilan berpikir elaboratif (Elaboration) dikatagorikan cukup baik dengan presentase $70,62 \%$ dengan keterampilan ini ditunjukan oleh perilaku peserta didik seperti mencari arti yang lebih mendalam terhadap jawaban atau pemecahan masalah dengan melakukan langkah-langkah yang terperinci dan mengembangkan gagasan orang lain. Hal tersebut selaras dengan pendapat Febrianti, dkk . (2016) tantang berpikir elaboratif yaitu kemampuan mengembangkan atau menambahkan ide-ide sehingga dihasilkan ide yang rinci atau detail. 
Berpikir kreatif siswa kelas IV di SD Negeri 3 Krakal sudah menunjukkan pada ranah cukup baik dilihat dari observasi yang telah dilakukan. Observasi dilaksanakan pada saat pembelajaran kewirausahaan oleh guru kelas, pada saat pembelajaran siswa telah memiliki kemampuan berpikir kreatif yang baik melalui kegiatan pembuatan produk berupa kalung, gelang dan cincin dari manik-manik pada saat praktikum pembelajaran kewirausahaan. Siswa yang memilki jiwa kreatif tinggi membuat kalung dengan model yang simetris dengan perpaduan warna dan jenis manik yang berbeda.bertanya dan memberi tanggapan pada saat pembelajaran kewirausahaan. Siswa juga diarahkan memberi merk produk yang sudah dibuat dengan nama "Karyaku" lalu siswa diberi kebebasan mengira-ngira harga yang sesuai dengan produk mereka, serta siswa dianjurkan menawarkan produk merka dilingkungan sekolah baik dikelas pada teman sebaya dan dikantor pada guru SD Negeri 3 Krakal. Kegiatan seperti diatas mampu memupuk jiwa kewirausahaan siswa kelas IV agar mampu menghadapi segala tantangan di era revolusi industry 4.0.

Berdasarkan hasil observasi untuk menganalisis kemampuan siswa berpikir kritis pada pembelajaran kewirausahaan pada 20 siswa kelas IV menunjukan hasil 70 $\%$ dimana hasil tersebut masuk kategori cukup baik. Hasil tersebut didapat dari siswa dengan nilai empat yang menunjukan siswa tersebut sangat kreatif dalam pembelajaran kewirausahaan, kemudian delapan siswa mendapat nilai tiga, dimana nilai tersebut masuk pada kategori kratif, dimana dalam pembelajaran kewirausahaan dengan mengahsilkan produk tersebut masih membutuhkan instruksi dari guru, sedangkan delapan siswa memperoleh point dua yang berarti siswa tersebut cukup kreatif dalam membuat produk manik-manik. Siswa yang mendapat point dua masih butuh arahan dari guru dan membuat produk manik-manik, dilihat dari hasil mereka belum simetris dalam menyusun dan kurang menarik. Mereka juga belum mampu memberi merk atau melabeling produk dan menawarkan produk yang mereka harus jual kepada konsumen. hal tersebut sejalan dengan pendapat Leis, M (2010) yang menyatakan bahwa kreativitas dan inovasi akan semakin berkembang jika siswa memiliki kesempatan untuk berpikir divergen. Siswa harus dipicu untuk berpikir diluar kebiasaan yang ada, melibatkan cara berpikir yang baru, memperoleh kesempatan untuk menyampaikan ide-ide dan solusi-solusi baru, mengajukan pertanyaan yang tidak lazim, dan mencoba mengajukan dugaan jawaban. Kesuksesan individu akan didapatkan oleh siswa yang memiliki ketrampilan kratif. Individu-individu yang sukses akan membuat dunia ini menjadi tempat yang lebih baik bagi semua masyarakat.

\section{SIMPULAN}

Berdasarkan hasil penelitian dan pembahasan maka dapat disimpulkan bahwa kemmampuan berpikir kreatif siswa pada pembelajaran kewirausahaan di SD 3 Krakal memiliki kriteria baik pada aspek berpikir lancar (Fluency) yaitu 78,75\%. Sedangkan pada kategori cukup baik adalah ketrampilan berpikir luwes Flexibility) dengan presentase sebesar $64,37 \%$, keterampilan berpikir orisinil (Originality ) prsentase $68,12 \%$ dan keterampilan berpikir elaboratif (Elaboration) sebanyak 70,62\%. Hal tersebut juga didukung dengan hasil observasi pada saat pembelajaran kewirausahaan yang masuk kategori cukup baik dengan prosentase $70 \%$.

\section{DAFTAR PUSTAKA}

Ali, M. (2013). Prosedur dan Strategi Penelitian Pendidik. Bandung: Angkasa.

Arnyana. (2016). Pengembangan Peta Pikiran Untuk Peningkatan Kecakapan Berpikir Kreatif Peserta didik. Jurnal Pendidikan dan Pengajaran UNDIKSHA, No. 3 hal 673.

Febriantika, dkk. (2016). Analisis Kemampuan Berpikir Kreatif Peserta Didik Dengan Memanfaatkan Lingkungan Pada Mata Pelajaran Ekonomi Di Sma Negeri 6 Palembang. Jurnal Profit Volume 3, Nomor 1. Universitas Sriwijaya. 
Leis, M. (2010). Challenges for the Future of Learning until 2030: Foresight on Learning, Inovation and Creativity. Presentation at Learn Tec 2010, Karlsruhe, DE.

Riduwan. (2012). Belajar Mudah Penelitian Untuk Guru-Karyawan dan Penelitian Pemula. Bandung: Alfabeta.

Sani. (2014). Pembelajaran saintifik untuk implementasi kurikulum 2013. Jakarta: Bumi Aksara.

Sudaryono, dkk. (2013). Pengembangan Instrument Penelitian Pendidikan. Yogyakarta: Graha IImu.

Susanto. (2013). Teori Belajar dan Pembelajaran di Sekolah Dasar.Jakarta: PT Fajar Interpratama Mandiri.

Zubaidah, S. (2017). Ketrampilan Abad ke-21: Keterampilan yang diajarkan melalui Pembelajaran. Universitas Negeri Malang. 